\title{
Sisterhood across different races and ethnicities
}

Natália Fontes de Oliveira

Mestre em Literaturas de Expressão Inglesa / UFMG

\begin{abstract}
This article argues that sisterhood among women characters from different races and ethnicities is possible and can help women characters fight against victimization and struggle for empowerment. To illustrate this idea Toni Morrison's novel $A$ mercy is analyzed and discussed.
\end{abstract}

Keywords

Sisterhood, race, Toni Morrison

As an African American writer, Toni Morrison has contributed significantly to the discussion about African American literature and literary criticism - especially that produced by black women writers - through her literary works and critical essays. In many of her novels, Morrison challenges preconceived ideas and depicts the implications of being a black woman during and after slavery. In this article, I discuss how sisterhood can represent a bond among women from various races and ethnicities. It is important to note that the term ethnicity is used to refer to the particular culture, tradition, language and ancestry of individuals. It differs from race because it does not assume that the characters are divided into genetically fixed determinants, but gives importance to time and place. Race and colonialism may be 'imbued with the same impetus to draw a binary distinction between 'civilized' and 'primitive' and the same necessity for the hierarchization of human types”. ${ }^{1}$ Although this thesis does not endorse in any way this hierarchization according to biological imperatives, the term race is also used and cannot be ignored because it is so strongly rooted in common usage. However, it is important to note that the term denotes a significant difference among

\footnotetext{
${ }^{1}$ ASHCROFT; GRIFFITHS; TIFFIN. The key concepts in post-colonial studies.
} 
individuals; that is, discrimination is inherent in the term. To ignore the term would be to pretend that all individuals are treated completely equally without suffering any marginalization. I argue for an alignment between individuals from different "races” and ethnicities as a way to destabilize these distinctions and maybe one day not to have to use the word race.

Regarding women bonds of sisterhood, Audre Lorde states, "[T]here is a pretense to homogeneity of experience covered by the word sisterhood that in fact does not exist”. ${ }^{2}$ The idea of a romantic sisterhood is refuted in this essay, being seen instead as complex interactions among a heterogeneous group of women characters. Although this study defends the notion of sisterhood among women from distinct races and ethnicities, some critics, such as Patricia Hill Collins, consider the relationship of sisterhood limited to black women. ${ }^{3}$ Even so, women from different heritage and backgrounds may also share similar traits as well as analogous experiences as they too are often subject to oppression and discrimination, creating a possibility for their sisterhood to flourish.

Differences among women characters are not ignored as these "differences present the most serious threat to the mobilizations of women's joint power". ${ }^{4}$ Instead, these distinctions are highlighted showing how they affect women bonding. To exclude women characters who are not black from the possibility of bonding through sisterhood can create stereotypes and contribute to a false notion that all black women are equal and they are the only ones who can understand and help each other. This notion would support another kind of discrimination, substituting the exclusion of black women with the social exclusion of colored women and white women. It is important to note that, as bell hooks points out, "[n]o transformative interventions can take place to end oppression and exploitation as long as we critique one form of domination and embrace another." ${ }^{25}$ hooks's statement shows the importance of not excluding women based on preordained biological aspects because it opens space for a new kind of marginalization. In addition, as Quashie’s explains:

The practice of being girlfriends (...) is not, cannot be, exclusive to an/others who are Black women. That is, the notion of being girlfriends, upon which

\footnotetext{
${ }^{2}$ LORDE. Age, race, class, and sex: women redefining difference, p. 189.

${ }^{3}$ COLLINS. Black feminist thought: knowledge, consciousness, and the politics of empowerment, p. 29.

${ }^{4}$ LORDE. Age, race, class, and sex: women redefining difference, p. 190.

${ }^{5}$ HOOKS. Outlaw culture: resisting representations, p. 204.
} 
the identification depends, is rooted in a political and spiritual solidarity, not merely a solidarity based on being, essentially a Black woman. In fact, the ultimate ethos of the identity is against reliance on easy coalitions and subjectivities that are granted. ${ }^{6}$

Sisterhood therefore depends on solidarity among women and should not be restricted to any biological determination, but should rather be marked by a willingness to care and help other marginalized women. Likewise, Elizabeth Schultz defends the possibility of interracial friendships by stating that: “One’s capacity for compassion, generosity, humor, and wonder is the basis for the friendship between two women". ${ }^{7}$ The fundamental aspect of sisterhood is based on the women characters' ability to come together in different ways and is not restricted to particular races or ethnicities.

Despite the difficulties that can arise from the ties among women from distinct heritages and backgrounds, Lorde ends her article "Age, race, class, and sex: women redefining difference" with a positive tone: "we sharpen self-definition by exposing the self in work and struggle together with those whom we define as different from ourselves, although

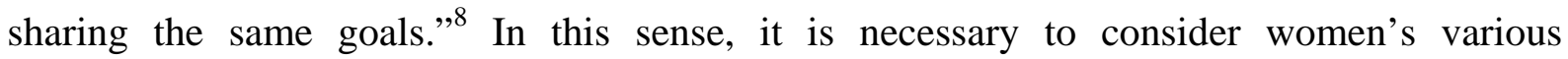
experiences and it is equally important to discuss how sisterhood allows the women characters to struggle for the same objectives. Bonds of sisterhood are not homogenous but rich in diversity as women from diverse ethnicities and races suffer different forms of discrimination. And still, they come together hoping to challenge such confinements.

hooks suggests that, instead of adopting a utopian vision of sisterhood, it is important to focus on a real sisterhood, one that considers the interests of everyone involved. ${ }^{9}$ The heterogeneous experiences of women and their specific needs should be considered for sisterhood to be effective. Besides, to establish unrealistic goals for women bonding, such as an immediate and complete liberation of women, or the end to patriarchy overnight can cause the impression that sisterhood does not in fact work or even exist. Actually, sisterhood can have many positive effects on the lives of women, but it is important to consider the specific social, cultural and the historical context as well as the experiences and backgrounds of each woman involved.

\footnotetext{
${ }^{6}$ QUASHIE. The other dancer as self: girlfriend selfhood in Toni Morrison's Sula and Alice Walker's The Color Purple, p. 203.

${ }^{7}$ SCHULTZ. Out of the woods and into the world: a study of interracial friendships between women in American novels, p. 69.

${ }^{8}$ LORDE. Age, race, class, and sex: women redefining difference, p. 195.

${ }^{9}$ HOOKS. Feminism is for everybody: passionate politics, p. 16.
} 
In order to illustrate the bonds of sisterhood among women characters from different races and ethnicities, this article analyzes Toni Morrison's A mercy (2008). The novel takes place in the 1680's during the early colonization of the United States of America. The narrative centers around the stories and relationships of four women: Rebekka, who is married to Jacob, a tradesman who seeks to become rich, and their slaves, Florens, Lina, and Sorrow. Each character has peculiar experiences and distinct world views, but they become interconnected as they depend on each other to survive in the wilderness. The friendships among Florens, an African American slave, and Jane, a white girl from a Presbyterian community; and Lina, a Native American slave, and Rebekka, her white European owner, are considered in order to expand the discussion about sisterhood among women characters from different backgrounds.

In the narrative, Rebekka falls sick and Florens is sent to find the blacksmith, a free lance worker who has helped around Jacob’s farm and once saved Sorrow from the same illness. While on her errand to get the blacksmith, Florens feels exhausted and she goes to a large house in search of shelter during the night. She describes the situation: "I decide to knock on the door of the largest house, the one that will have a servant inside (...) It is in the single lit house in the village so I choose to go there." ${ }^{10}$ From the inside of the house, comes Widow Ealing and Florens describes her as "much taller than Mistress or Lina and has green eyes. The rest of her is a brown frock and a white cap. Red hair edges it". ${ }^{11}$ Florens is impressed by her looks because she has not seen women with such complexions before. The widow is hesitant to help Florens and asks her many questions: "Who hath sent you she asks . . . She looks behind me left and right and asks if I have no protection, no companion (...) She narrows her eyes and asks if I am of this earth or elsewhere (...) Christian or heathen.”" is very cautious as she lives in a small conservative religious community. Although she knows Florens may bother the community, the Widow Ealing allows her to stay.

Florens enters the house and only her after eating something she notices a girl is also there. The girl gets up and Florens watches her: "She stands then and limps to the table where the lamp burns. Holding it waist high she lifts her skirts. I see dark blood beetling down her legs. In the light pouring over her pale skin her wounds look like live jewels.”13 The Widow

\footnotetext{
${ }^{10}$ MORRISON. A mercy, p. 106.

${ }^{11}$ MORRISON. A mercy, p. 106.

${ }^{12}$ MORRISON. A mercy, p. 106-107.

${ }^{13}$ MORRISON. A mercy, p. 108.
} 
tells Florens: "This is my daughter Jane (...) Those lashes may save her life.”14 Jane suffers the consequences of not being considered human in that restricted religious community because of the shape of her eye. Florens witnesses her "holding her face in her hands while the Widow freshens the leg wounds. New strips of blood gleam among the dry ones". ${ }^{15}$ To prove to the community that her daughter is not a demon, the Widow Ealing has to make Jane bleed as it was believed that only humans could bleed.

In the morning, when the members of the community arrive in the house, they are astonished by Florens’s appearance: “One of the women covers her eyes saying God help us. The little girl wails and rocks back and forth.”16 The town representatives, who were coming to see Jane, forget about her, concentrating on what they perceive as Florens's disturbing blackness. Everyone starts to point at her and to talk about what is to be done about this mysterious and bizarre girl. Florens says: "I shout, please sir. I think they have shock that I can talk. Let me show you my letter I say quieter. It proves I am nobody's minion but my Mistress.”17 Florens direct explanation of events highlights the racist view of the villagers and how they are quick to judge her as inferior based on her skin color. The only person who dares to come close to Florens is Jane's mother who gets the letter "and offers it but no one will touch it. The man orders me to place it on the table”. ${ }^{18}$ Rebekka had written a letter explaining that Florens belongs to her and she is on an errand. The town representatives are shocked and, the little girl does not stop crying, so everyone rushes out and orders Florens and Jane to stay in the house. When both girls are left alone, they have time to perceive each other's suffering and their rejection by that community. Florens sympathizes with Jane's misery and Jane is thankful because for once she is not the major focus and the problem for the community and, in addition, identifies with Florens.

Both girls know the difficulty of being misjudged and marginalized. In fact, they have a lot in common. Their bond stems from their recognition of their status as outsiders. Consequently, Jane decides to ignore the orders given by the head of the community and leads Florens away from the village by showing her an escape route. Florens explains: "We come to

\footnotetext{
${ }^{14}$ MORRISON. A mercy, p. 108.

${ }^{15}$ MORRISON. A mercy, p. 109.

${ }^{16}$ MORRISON. A mercy, p. 111.

${ }^{17}$ MORRISON. A mercy, p. 111.

${ }^{18}$ MORRISON. A mercy, p. 111.
} 
a stream (...) Daughter Jane hands me the cloth of eggs. She explains how I am to go.”19 Jane shows her how to get away and gives her food for the journey. This event shows the strength of women bonds and that sisterhood is possible among women from different races and ethnicities because their "coupling is an alliance, a political and spiritual union" ${ }^{20}$ An alliance between Florens and Jane is possible because they identify with and care for each other, and because of their shared otherness.

Angela Davis argues, “[S]isterhood between black and white women was indeed possible and as long as it stood on a firm foundation it could give birth to earthshaking accomplishments”. ${ }^{21}$ Florens and Jane's friendship shows that it is possible for black and white women to establish sisterhood bonds as they unite and help each other even if temporarily. A comparison can be made with Morrison's Beloved. In the novel, while Sethe is running away she sees Amy, a white woman, who helps her give birth during her escape. While analyzing Beloved, Davies suggests that these bonds are "representative of the paradoxical separations and commonalities among women”. ${ }^{22}$ A similar view can also be applied to Florens and Jane's sisterhood. Describing Sethe and Amy's situation, Davies recognizes that "in a society stratified along race, class and gender lines (...) [they] may form a temporary alliance around the need to give birth, inevitably they take divergent paths to freedom". ${ }^{23}$ Sethe and Amy are momentarily united in a bond that saves Sethe and her baby. Florens's bond with Jane is also temporary, but nonetheless crucial, as Amy helps Florens escape. Although they will lead different paths afterwards, they care for each other and come together through sisterhood.

Another important sisterhood bond in A mercy arises between Lina and Rebekka. Lina is the first woman slave Jacob buys to help him with the farm. She arrives before Rebekka, who is suspicious of her, but as both are left alone in the farm most of the time, they slowly become fond of each other. They eventually become friends and when "the first infant was born, Lina handled it so tenderly, with such knowing, Rebekka was ashamed of her early fears

\footnotetext{
${ }^{19}$ MORRISON. A mercy, p. 114.

20 QUASHIE. The other dancer as self: girlfriend selfhood in Toni Morrison's Sula and Alice Walker's The color purple, p. 207.

${ }^{21}$ DAVIS. Women, race, and class, p. 104.

22 DAVIES. Black women, writing and identity: migrations of the subject, p. 140.

${ }^{23}$ DAVIES. Black women, writing and identity: migrations of the subject, p. 140.
} 
and pretended she'd never had them”. ${ }^{24}$ Both were quite young, in their late teens, and, although Rebekka is the mistress of the house, she is still inexperienced and needs Lina's help, who in turn, longs for companionship.

Their class and racial difference are minimized because there is a "focus on building community" 25 as they try to create a pleasant environment for them to live in. Both understand that "fraudulent competition was worth nothing on land that demanding"26 and that they "were company for each other". ${ }^{27}$ In order to work the land they have no time to think about their differences, they have to stick together to overcome the hardships imposed by the land and weather. Thus, Lina and Rebekka:

Became friends. Not only because somebody had to pull the wasp sting from the other's arm. Not only because it took two to push the cow away from the fence. Not only because one had to hold the head while the other one tied the trotters. Mostly because neither knew precisely what they were doing or how. Together, by trial and error they learned. ${ }^{28}$

Sisterhood offers both a way to stay alive because as long as they can count on each other, they are able to endure the difficulties of trying to run a farm by themselves and compensate for their vulnerability of being women in a sexist society. As the narrator comments: "Although they had nothing in common with the views of each other, they had everything in common with one thing: the promise and threat of men. Here, they agreed, was where security and risk lay. And both had come to terms." ${ }^{29}$ Despite their differences, they are united through sisterhood by identifying with each other's limitations and helping each other survive as two women mostly alone in the wilderness.

As I have discussed in this paper, there are various types of bonding among the characters. Sisterhood is present between Lina and Rebekka as both women rely on each other to overcome the hardships of being women and alone in the wilderness. Through sisterhood, Florens and Jane overcome their differences by identifying with each other's sufferings. Their encounter is brief but nevertheless crucial because they provide alternative circumstances for each other by defying the rigid structures of a narrow-minded community. Sisterhood has to

\footnotetext{
${ }^{24}$ MORRISON. A mercy, p. 75.

${ }^{25}$ HOOKS. Sisters of the yam: black women and self-recovery, p. 154.

${ }^{26}$ MORRISON. A mercy, p. 53.

${ }^{27}$ MORRISON. A mercy, p. 53.

${ }^{28}$ MORRISON. A mercy, p. 53.

${ }^{29}$ MORRISON. A mercy, p. 98.
} 
be considered according to specific circumstances and has to be problematized, because the women characters, more often than not, do care about each other. However, they are often judged too harshly as they are expected to completely transcend their environment like supernatural heroes.

This article shows how sisterhood in Morrison's Mercy is marked by a complex interaction among the women characters that cannot be determined by preconceived stereotypes or essentialisms. In the novel analyzed, friendship among African American women and women from different races, ethnicities and backgrounds create the opportunity for the characters to fight against victimization as well as to struggle for empowerment. Considering that the narrative is recent, written in 2008, the various types of bonds may suggest that nowadays greater importance is given to the interaction among women, respecting their differences and to how sisterhood can help each woman. More fluid and dialectic categories are accepted as essentialism is rejected and each character is perceived not only through their complex singularities but also through the similarities that make their union successful.

\begin{abstract}
RESUMO
Este artigo argumenta que irmandade entre personagens femininas de raças e etnias diferentes é possível, sendo que esses laços ajudam as personagens a lutarem contra vitimização e por empoderamento. Para tal, a obra A mercy de Toni Morrison, é analisada e discutida.
\end{abstract}

\title{
PALAVRAS-CHAVE
}

Irmandade, raça, Toni Morrison

\section{REFERENCES}

ASHCROFT, Bill; GRIFFITHS, Gareth; TIFFIN, Helen. Key concepts in post-colonial Studies. New York: Routledge, 1998.

COLLINS, Patricia Hill. Black feminist thought: knowledge, consciousness, and the politics of empowerment. New York: Routledge, 2000.

DAVIES, Carole Boyce. Black women, writing and identity: migrations of the subject. New York: Routledge, 1994.

DAVIS, Angela. Women, race, and class. London: The Women’s Press, 1982. 
HOOKS, bell. Feminism is for everybody: passionate politics. London: Pluto, 2000.

HOOKS, bell. Outlaw culture: resisting representations. New York: Routledge, 1994.

HOOKS, bell. Sisters of the yam: black women and self-recovery. Boston: South End, 1993.

LORDE, Audre. Age, race, class, and sex: women redefining difference. In: LORDE, Audre (Ed.). Sister outsider. California: Crossing Press, 1984. p. 114-124.

MORRISON, Toni. A mercy. New York: Alfred A. Knoff, 2009.

MORRISON, Toni. Sula. New York: Penguin, 1973.

QUASHIE, Kevin Everod. The other Dancer as self: girlfriend selfhood in Toni Morrison's Sula and Alice Walker's The color purple. 2001. Meridians: Feminism, Race, Transnationalism. Disponível em: <http://www.hwwilson.com>. Acesso em: 8 nov. 2009.

SCHULTZ, Elizabeth. Out of the woods and into the world: a study of interracial friendships between women in American novels. In: PRYSE, Marjorie; SPILLERS, Hortense (Ed.). Conjuring black women, fiction, and literary tradition. Bloomington: Indiana University Press, 1985. p. 67-84. 